\title{
A Trust-Based Blockchain System for Production and Comprehension of Implicatures by Middle Eastern Speakers of English
}

\author{
Sami hussein ( $\sim$ Samihusseinhakeembarzani@gmail.com ) \\ Cyprus International University: Uluslararasi Kibris Universitesi \\ Behbood Mohammadzadeh \\ Cyprus International University: Uluslararasi Kibris Universitesi
}

\section{Research Article}

Keywords: pragmatic competence, implicature, communication, Trust- based blockchain system

Posted Date: October 25th, 2021

DOI: https://doi.org/10.21203/rs.3.rs-941538/v1

License: (c) (i) This work is licensed under a Creative Commons Attribution 4.0 International License. Read Full License 


\section{Abstract}

This research examined how well Kurdish EFL students interpret and generate implicatures in the same way as native English speakers do. Thus, a multiple-choice discourse completion test and a written discourse completion task were answered by 109 Kurdish EFL university students (42 males and 67 females) and 20 native English speakers (7 males and 13 females). The data were analyzed using SPSS, the Gricean framework (1975), and a rating rubric developed by Jernigan (2007). The results unveiled Kurdish EFL learners have a low level of implicature comprehension as well as production. As opposed to particularized implicatures, participants were more successful in the interpretation of generalized ones. Data showed learners had difficulty understanding conversational implicatures that are context-dependent and sensitive to culture. Data also revealed that transfer of knowledge and mother tongue seem to govern the way in which they comprehend and produce implicatures.Moreover, the findings showed female learners outperformed their male counterparts in the tests. Likewise, private university learners performed better than public university students. Since this examination contains huge amount of data, security is a major concern. Blockchain provides a creative technique to store data, perform functions, and establish trust in an open environment. Hence, the entire analysis is performed in a trust- based blockchain system for the security and privacy of the data.

\section{Introduction}

Today, globalization and current ongoing changes in the world demand interconnection among people worldwide. That is, the need and essence for single use of language for communication is becoming a reality, and it is more apparent than any time before. In this line, Siddiqui (2018) states it is nearly difficult to connect with people and take an active role in a conversation without knowing a shared language. Though it is a controversial issue, English, as the most beloved and dominant language in different spheres of life, is very close to being the global and single means of communication than any other languages (Barzani, 2020).

Keeping this in mind, people are profoundly multifaceted communicators. Possibly, the complexity of the nature of communication between people primarily relates to how they converse. They mean to expressfurther the words they articulate, and in the same way, the addressed listeners must look beyond the uttered words to reach the intended interpretation. Arguably, as to the points mentioned earlier, the most apparentpurpose for learning a subsequent language is communication. Yet, what makes communication among people more complex is that each language possesses far unlike characteristics, not only linguistic differences but also cultural variances (Rizk, 2003). For instance, in certain societies, a regular rejection act is expressed using loud voices, whereas, in other cultures, speakers perform the same rejection act with a relatively soft voice. Or, in certain cultures, it is normal behavior to ask people about their salary and age, while it is quite inappropriate to some other cultures. Undoubtedly, culture and language are inseparable; that is to say, acquiring a second language should be followed by acquiring its culture (Spackman, 2009). So that, these variances might, to a great extent, result in misunderstanding, communication failure, and inappropriateness among language learners while launching a conversation in the target language ( $T L)$. In addition, societies that migrate also experience problems with communication. The most immigration Turkey (45\%) school-age population and the fact that the extensive majority of this country gave significance to refugee children's education due to the children population. Is the biggest and priority threats in the refugee language issues of children obtaining education in Turkey. Several projects are produced to remove educational challenges. This in Turkey by the EU as one of the projects "The refugees are within the scope of Temporary Protection" of humanitarian support, education, health, psycho-social assistance and migration maintenance as areas that are straightforwardly funded by MONE (Sipahi, 2021). 
In the light of the above mentioned issues, for various reasons, just like people living in immigrant societiesEFL students, when comes to communication in the target language,face these difficulties. Teaching English inthe Iraqi Kurdistan region as a foreign languagefocuses on linguistics more than the practical aspects of the language; this crucial aspect has not been researchedadequately either. Therefore, to meet the research aims and address the gap perceived in literature, this study endeavors to address and answer the succeeding investigation questions.

-What is the level of Pragmatic Competence of Kurdish EEL learners in terms of comprehension of implicatures? -What is the degree of Pragmatic Competence of Kurdish EEL learners in terms of the production of implicatures? -What are the resemblances and variations between Kurdish EFL learners and those of native speakers of English regarding production and comprehension of implicatures?

-To what extent do Kurdish EFL learners commit pragmatic transfer?

-Do Kurdish EFL learners exhibit variations in the comprehension and production of implicatures concerning implicature types, university type, and gender?

\section{Theoretical Framework}

Undeniably, to learn and master a language; to become a near-native speaker, more importantly, to communicate appropriately and successfully not only involves linguistic competence, but a good knowledge of pragmatic competence is required either (Olshtain \& Cohen, 1983; Thomas, 1983; Blum-Kulka and Olshtain, 1984; Anderson, 1990; Wolfson, 1989; Bardovi-Harlig \& Griffin, 2005). Pragmatic skillisacrucialaspectof language improvement. It entailscoping with functional language and the frameworks in which it functions; thus, competence in pragmatics contributestoaccomplishing specific goals and decoding the language in context. Pragmatics is considered a branch of linguistics, and it has been stated variously. Yet, more or less, the given concepts offer the same idea. To Levinson (1983), pragmatics essentially covers the analysis of the usage of language. Yule (2010) stated pragmatics as "the study of "invisible" meaning, or how we realize what is meant even when it isn't said or written." In a nutshell, it can be briefed that pragmatics is the analysis of the interpretation and conveyance of meaning intended indirectly in a communication.

Mey (2006) indicates that there is always the possibility of misunderstanding between people in intercultural interactions due to various cultural and social backgrounds. Moreover, a robust body of work on L2 learners' pragmatic skills has indicated that linguistic improvement may not necessarily lead to a similar degree of pragmatic progression (Bardovi-Harlig and Dornyei, 1998; Krasner, 1999). So, even advanced learners are expected to face difficulties of comprehension or expression of the intended intentions and values of conduct and politeness. Thomas (1983); Leech (1983); and Bardovi-harlig and Dornyei (1998) have stated that "EFL learners may produce utterances that are perfectly grammatical, but they may violate social norms of the target language because they lack pragmatic competence (appropriateness of meaning) to support grammatical competence (appropriateness of form)" (as cited in Farashaiyan, \& Hua, 2012, p. 35). In the same line, Eslami-Rasekh and Fatahi (2004) also cautioned that EFL learners' lack of pragmatic competence would cause pragmatic failure while communicating with native speakers. Pragmatic failure denotes the incapability to comprehend and decode from what is uttered (Thomas, 1983).

Tulgar (2016) states that "language operators are required to stick toa series of conventions in which to ensure their conversation is not only substantiative but also relevant." 
Long ago, pragmatic competence was not of the interest of researchers, language experts, scholars, and even syllabus designers. In other words, the knowledge of linguistic or grammatical principles was exclusively equated with acquiring a second language. In this line, Dornyei and Thurell (1991) indicate that the primary goal of language acquisition in schools has historically been to develop students' linguistic skills. Nevertheless, pragmatic competence, more precisely, the mastery of the practical usage of language, has obtained a lot of attraction from scholars, particularly in the area of language education, shortly after Chomsky(1977) introduced the concept "pragmatic competence" in addition to the implementation of communicative competence models(Bachman, 1990; Bachman \& Palmer, 1996; Canale, 1983; Canale\& Swain, 1980). From then, priority was given to enable learners to use the $T L$ in real-life contexts. Attempts are undertaken to enable $L 2$ learners to communicate almost challenge-free in real-life contexts using the target language. One can communicate appropriately when he/she has been given awareness about pragmatic rules of the target language rather than only been equipped with linguistic knowledge. This is not intended to diminish the importance of grammar; instead, it stresses that learning grammatical skills on its own does not guaranteeacceptable and socially correct language use in real-life circumstances.

Therefore, since one of the primary sources of cross-cultural interaction break-down is because of deficiency of knowledge of pragmatic competence, undoubtedly, in language teaching, especially in EFL contexts, the teaching of pragmatic competence should be given priority, and learners shall be given awareness.

In nearly the last two decades in Iraq, in general, and in the Kurdistan Region of Iraq, the English language's superiority considerations have been echoed in specific. English has been rooted in the curricula of the education system steadily. English instruction is a main and compulsory subject which starts from the very first year of public and private schools, and then to the university levels, yet according to Sofi-Karim (2015) and based on personal experience, upon graduation, few students mainly from the public sector can communicate well in English. The problem, to a great extent, is due to the teaching methodology being followed.

L2 learners' pragmatic competence will not progress by itself. In essence, it is generally agreed that access and disclosure to the target language is the central means for its attainment. This illuminates that in the contexts where English is a foreign language (EFL), the situation becomes more difficult for the learners as access to the authentic input and chances of using the target language is inadequate (Cenoz, 2007).

Many studies within interlanguage pragmatics (ILP) have been conducted to investigate and address such learner challenges. While a visible body of ILP research has been devotedto compare the speech acts performanceofEnglish language learners to native speakerscross-culturally, only a limitedportion is allocated to the studies of implicatures. This is to clarify that pragmatics is not only knowledge of speech acts, but knowledge of implicatures matters significantly either. Therefore, this study aims to address and focus on implicatures.

\section{Implicature - The Analysis Of How More Gets Interacted Than Said}

Implicature is one of the five main areas within pragmatic competence (Levinson, 1983, p. 97). People often say something to mean something else; therefore, it is not easy to figure out the intended meaning (implicature). Research has suggested that conventions governing communication or speech acts differ dramatically among various cultures and languages (Keenan, 1976; Olshtain\& Cohen, 1989; Eierzbicka, 1991; Lee, 1987). Conversely, several theorists indicate that specific rules govern communication in any language (Grice, 1975; Fraser, 1980; Brow \& Levinson, 1987). The notion of implicature was first introduced by Grice (1975) "to denote the implications of an utterance that are not strictly implied by its content." He claims that conversations between two or more people for a particular purpose, as the interchange of data, are "cooperative efforts." In which interlocutors follow certain 
conventions to mean more than what they utter and interpret the implied meaning. To do so, discussers must adhere to several conversational maxims in which he labelled as "cooperative principle." This has been defined in four different maxims, namely quantity, quality, manner, and relation. The Quantity Maxim requires one only to give the amount of information asked for, no more. The Quality Maxim specifies that one should utter the truth and abstain from saying things which one lacks knowledge for. However, The Maxim of Relation indicates that one should strict about the topic while asking questions and giving answers. Finally, the Maxim of Manner commits one to be orderly, brief, clear, avoiding obscurity and ambiguity in communication.

Nevertheless, Grice suggested the speakers can violate these maxims in different ways: either unostentatiously, which is to mislead people, unintentionally not observing a maxim due to defective linguistic performance, opting out a maxim to show the unwillingness of cooperating, or floating a maxim to lead the addressee to look for a covert, implied meaning.

Non-observance of each Maxim would result in some sorts of intended and indirect meanings. Grice (1975) identified two kinds of such meanings, conversational and traditional implicatures. The first one occurs when "the speaker fails to monitor the maxims of cooperation, but the expected meaning shall still be understood (Schauer, 2009); hence, "speakers' adherence to those maxims is maintained not at a superficial level, but rather at a deeper level" (Grice, 1981). Whereas the latter mainly depend on traditional semantic meanings of the words selected in the speech, in spite of the particular context in which they happen (Grice, 1989, p. 25). The current study aims at looking at the intentional non-observance of a maxim to achieve certain communicative purposes termed conversationalimplicatures. For instance,

\{door knocks\}

Jack: "could you open the door, Emily?"

Emily: "I am tied up with cleaning."

In this context, Emily is not observing the Maxim of relevance, in which she gave a response quite unrelated to Jack's question, instead of providing a direct response such as "No" Yet, Jack undertakes that Emily is following cooperative principle; therefore, he makes an association that being tied up with cleaning indicates she is not able to open the door.

Clark and Clark (1977) suggested for decoding an appropriate interpretation from such intended meanings, the addressee must intake the message based on a hypothesis of what is being given, in addition to depending on social background knowledge and expectations. Interpretation of such messages is also not context-free and is based on a piece of common knowledge, either cultural or social. The most prominent research in this area is by Bouton. In 1994, he investigated the comparison between non-native English-speaking students and native speakers regarding their interpretation of conversational implicatures and the impact of explicit instruction on the development of such knowledge. The results uncovered an important variation between the two groups in which nonnative international learners of English performed poorer than native ones. Regarding the implicit instruction of conversational implicatures, the findings revealed that it helped them progress in their interpretations. This indicates that this area of language, as like many other areas, is teachable.Similarly, Lee (2002) studied the interpretation of Korean EFL learners' implicature to those of Native speakers of English. Results indicated that native and non-native speakers significantly vary in their interpretation of particularized conversational implicatures. It was also revealed that cultural knowledge, personal biases, stereotypes, and the transmission of knowledge from a language to 
another seem to govern the way people decode the indirect meaning.Moreover, Viljamaa, H. (2012) researched the pragmatic competence of Finnish learners of English. Data were gathered through a multiple-choice discourse completion task from 56 EFL eighth graders and 63 CLIL. The findings uncovered that, on average, $72.5 \%$ of the learners' answers were correct; therefore, it revealed that the pragmatic competence level of Finish learners of English is quite well.Similarly, to investigate pragmatic competence in terms of awareness and production among Chinese EFL learners, Li, Rui, Suleiman, Raja, and Sazalie, Azima (2015) conducted a study. The results of the study revealed that Chinese EFL learners' pragmatic awareness and production is not satisfying.

In any way, comprehension of implicature needs decoding linguistic and contextual cues to make inferences. This task is demanding for EFL learners as they mustrecognize the gap between the literal utterance and the expected meaning to infer the implied message. The maximum the gap is, the maximum the comprehension load becomes. Thus, in such cross-cultural contexts, those learners not having a good command of English or who have not reached a native-like proficiency would find it rather difficult in coming to an absolute interpretation. So that, the present study, to better understand and illustrate such differences, attempts to find out the status of pragmatic competence of Kurdish EFL learners comparing to those of native speakers regarding their production and comprehension of implicatures.

\section{Methodology}

This analysis utilized a descriptive and quantitative investigation design. The notion of using this research design was due to its appropriateness and feasibility to address the research aims and to answer the research questions adequately.

\section{Participants And Setting}

The selected sample was vastly diverse concerning language proficiency, age, gender, years of studying English, educational background, contact with native speakers, and visit to an English-speaking country. The study comprised two group participants, as shown in Table 1 below. The first group included 109 Kurdish EFL university students (KEFLUS) in the Iraqi Kurdistan Region. The second group consisted of 20 native English speakers (NSE) holding varying academic degrees and from different countries.

Table 1

Number of participants in both groups

\begin{tabular}{|llll|}
\hline Participants & Male & Female & Total \\
\hline Kurdish EFL University Students & 42 & 67 & 109 \\
\hline Native Speaker of English & 7 & 13 & 20 \\
\hline Total & 50 & 79 & 129 \\
\hline
\end{tabular}

Table 2 below illustrates a detailed picture of the first group participants (KEFLUS). It is worth mentioning that these participants were from four state and three private universities, from three different cities of the Iraqi Kurdistan Region. Taking samples from different cities and universities would give a clearer and reliable picture of the issue under investigation. The study employed a convenience sampling method for the selection of the participants. That is, the participants were chosen depending on their availability and interest to participate. 
Table 2

Kurdish EFL University Students

\begin{tabular}{|c|c|c|c|c|c|c|c|c|c|c|c|}
\hline \multirow[t]{2}{*}{ No. } & \multirow[t]{2}{*}{ University } & \multirow[t]{2}{*}{ College } & \multirow{2}{*}{$\begin{array}{l}\text { University } \\
\text { type }\end{array}$} & \multicolumn{4}{|c|}{ Stage } & \multicolumn{2}{|c|}{ Gender } & \multirow[t]{2}{*}{ Age } & \multirow[t]{2}{*}{ Number } \\
\hline & & & & 1st & 2nd & 3rd & 4th & Male & Female & & \\
\hline 1 & Salahaddin & Languages & State & & 3 & 6 & 12 & 9 & 12 & $\begin{array}{l}19- \\
24\end{array}$ & 21 \\
\hline 2 & Duhok & Arts & State & & 4 & 8 & 3 & 5 & 10 & $\begin{array}{l}19- \\
24\end{array}$ & 15 \\
\hline 3 & Akre & Education & State & & & 6 & 3 & 7 & 2 & $\begin{array}{l}19- \\
24\end{array}$ & 9 \\
\hline 4 & Cihan & Education & Private & & 7 & 2 & 5 & 6 & 8 & $\begin{array}{l}19- \\
24\end{array}$ & 14 \\
\hline 5 & LFU & Education & Private & & & 5 & 9 & 4 & 10 & $\begin{array}{l}19- \\
24\end{array}$ & 14 \\
\hline 6 & TIU & Education & Private & & & 19 & & 6 & 13 & $\begin{array}{l}19- \\
24\end{array}$ & 19 \\
\hline 7 & Soran & Arts & State & & & 3 & 14 & 5 & 12 & $\begin{array}{l}19- \\
24\end{array}$ & 17 \\
\hline Total & & & & & 14 & 49 & 46 & 42 & 67 & & 109 \\
\hline
\end{tabular}

\section{Data Collection Tools}

The present study utilized two data collection instruments to answer the investigation questions and address the investigation aims. The researchers devised the employed tools. Prior to that, the main works in pragmatic were reviewed, and several experts in the field were consulted. Similarly, a variety of layouts and questions used in ILP studies were referred to. Then, the instruments were pilotedafore the final conduction.

\section{Multiple-Choice Discourse Completion Task (MDCT)}

To investigate the Kurdish EFL learners' comprehension of implicatures, a MDCT was employed. Jianda (2006, p. 4) defined MDCT as "test items that require the test taker to select the correct answer from a number offered options." The MDCT used in the study contains 19 items representing the four maxims, as shown in Table 4 below. 
Table 3

The MDCT Item Specifications

\begin{tabular}{|ll|}
\hline Quantity & Implied Meaning Types \\
\hline 4 & Distracters \\
2 & Quantity- indirect negative criticism \\
2 & Quantity- be sufficiently informative \\
2 & Quality- irony-sarcasm \\
1 & Quality- pope question \\
4 & Relevance- topic change \\
1 & Relevance- set conventional expressions \\
1 & Manner- ambiguity \\
\hline
\end{tabular}

Each item in the MDCT comprises of a narration of a situation and a dialogue followed by a question requiring the test taker to choose one of the provided four options. As to the scoring, 1 point was assigned to each correct answer, and other options were received 0 points. The four distractoritems were removed from the analysis. Table 5 visualises an example from the test.

Table 4

Sample Item from MDCT

\section{Item 14. Relevance implicature}

Clara, a student, wants to meet Prof. Dr. Ellen, the head of the department.

Clara: "Is Prof. Dr. Ellen available, secretary? May I see him?"

Secretary: "It is Wednesday."

What the secretary is saying is that...

a. She doesn't know where Dr. Ellen is.

b. She thought Clara wants to know what day it is.

c. She doesn't know whether Dr. Ellen is available.

d. She thinks Clara can't meet Dr. Ellen.

\section{Written Discourse Completion Task (WDCT)}

To collect data regarding the Kurdish EFL learners' production of implicatures, a WDCT was utilized. Kasper and Dahl (1991, p. 221) defined it as "written questionnaires enclosing several short explanations of the situation, followed by a short dialogue with a space for the speech act being examined." The WDCT was in the form of an open-ended questionnaire. It comprises 12 items; each comprises of a description of a situation succeeded by a question requiring the participant to write something accordingly. Table 6 below shows a sample of the situations. 
Table 5

Sample Item from WDCT

Situation 5

A friend of yours gave a presentation in the English class. After the class, he comes to you and asks your opinion about it. You imagine the presentation was not good at all, it was not attractive, and the idea was not clear. You don't want to discourage your friend, but you also don't want to lie regarding the presentation's poor quality.

What would you say?

Your friend: "How was my presentation?"

You:

The hypothetical situations are set regarding specific differences in social distance, power, and relative status between the interlocutors. That is, the interpretations of the participants' responses were interpreted accordingly.

\section{Data Analysis}

Data collected in response to the learners' comprehension of implicatures were numeric in nature. The data were coded into spreadsheets; each correct response marked " 1 " whereas each wrong option referred as "0". Therefore, the collected data were required quantitative analysis. To do so, the descriptive and inferential statistics were run utilizing the Statistical Package for the Social Science (SPSS) version 22. The examination was carried out with the help of Muijs' (2004) instructional manual. As the data forming the production of implicatures were in written form, the analysis was more laborious, unlike the comprehension data. That is, the analysis required a more detailed descriptive process. To do so, certain steps were followed: 1. coding, 2. explaining the coded data, 3. rating procedures, and finally 4 . drawing conclusions.

\section{Results}

This part provides the outcomes obtained after the administration of the two pragmatic instruments. First, the implicature comprehension results are presented, and then implicature production ones are offered.

\section{Comprehension of Implicatures in the L2}

The study's first research issue was to assess the extent of knowledge of Kurdish EFL learners' comprehension of implicatures in L2. As observed in Table 6 below, a minimum level of achievement is recorded. That is, the mean score of the participants is 7.66 out of $15(S D=3.30, \min =3, \max =15)$. This shows Kurdish EFL learners' low level of pragmatic competence in terms of implicature comprehension. 
Table 6

Descriptive Statistics for MDCT

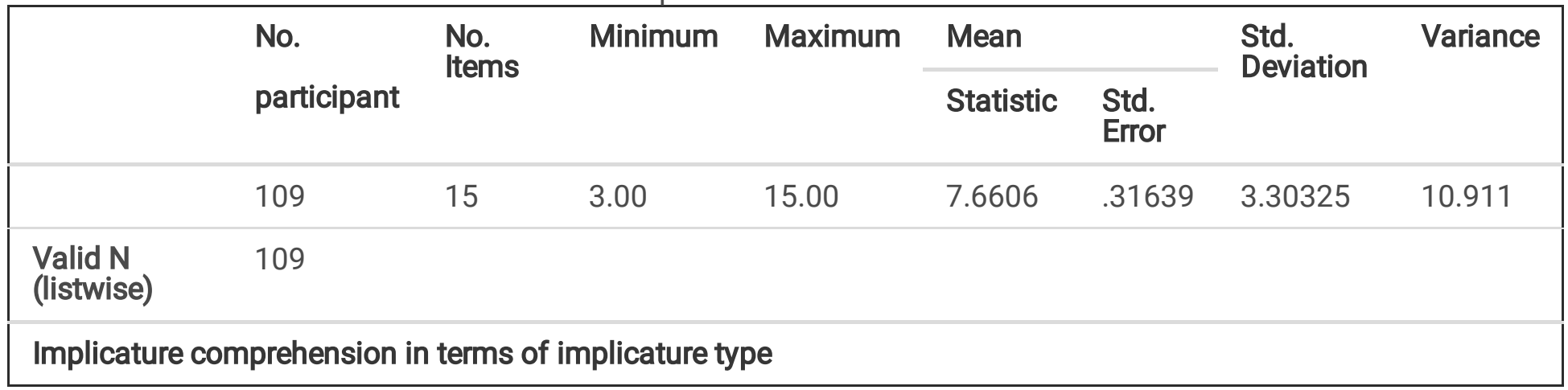

The average progress ratings for the flouting of the four major maxims of conversation were measured to illustrate and explain the variations in understanding each type within broader categories. As presented in Table 7, the level of success varies across the four main types. The findings show that the highest success rate is in the Relevance Maxim with (67.54), followed by a slight difference in Maxims of Manner, Quality, and Quantity(respectively, 54.6, 49.1-41.3, \&40.85-28.45).

Table 7

Comprehension perimplicature type

\begin{tabular}{|lll|}
\hline Implicature type & Description & \% Correct response \\
\hline Quantity & indirect negative criticism & 28.45 \\
\cline { 2 - 3 } & be sufficiently informative & 40.85 \\
Quality & irony-sarcasm & 49.1 \\
\cline { 2 - 3 } & pope question & 41.3 \\
\hline Relevance & Be relevant & 67.54 \\
\hline Manner & Be orderly & 54.6 \\
\hline
\end{tabular}

The participants' progress rates in interpreting strongly context-dependent and context-independent implicatures, respectively, particularized, and generalizedimplicatures, were addressed to further clarify some other relevant issues. As Table 8 directs, participants were more successful in the interpretationof particularizedones when opposed to generalized implicatures. This indicates the importance of culture in learning a second language. Likewise, it shows the lack of cultural awareness given to Kurdish EFL learners in teaching. This also leads to the interpretation of mother tongue cultural issues in the realization of implied meanings.

Table 8

Correct responses per generalized\&particularizedtypes

\begin{tabular}{|lll|}
\hline Implicature type & Items & \% Correct answers \\
\hline Particularized implicature & $3,4,8,9,12,13,16,18$ & 43.25 \\
\hline Generalizedimplicature & $2,6,7,11,14,17,19$ & 60.04 \\
\hline
\end{tabular}

Gender-based comparison of implicature comprehension 
Due to the debatable issues of female superiority in pragmatic competence, the study further intended to address this new issue among Kurdish EFL learners. As Table 9 projects, a difference between male and female learners is revealed in which female learners performed higher $(M=8.31, S D=3.08)$ than their male counterparts $(M=6.61, S D=$ 3.41). The independent t-test showed that by traditional criteria, this variation is regarded to be very statistically significantdf (107)P-value=0.0085, $p<0.05$.

Table 9

Independent t-test between the scores of Male and Female learners

\begin{tabular}{|ccccccccc|}
\hline Gender & N & Mean & $\begin{array}{l}\text { Std. } \\
\text { Deviation }\end{array}$ & $\begin{array}{l}\text { Std. Error } \\
\text { Mean }\end{array}$ & $\begin{array}{l}\text { Std. Error } \\
\text { Difference }\end{array}$ & df & t & $\begin{array}{l}\text { Sig. (2- } \\
\text { tailed) }\end{array}$ \\
\hline Male & 42 & 6.6190 & 3.41412 & .52681 & .63228 & 107 & 2.680 & 0.0085 \\
\hline Female & 67 & 8.3134 & 3.08078 & .37638 & .64745 & & \\
\hline
\end{tabular}

Moreover, an analysis of the two groups (male \& female) concerning the comprehension of the implicature types (Generalized\&Particularized)(see Table 10) found that both groups performedhigher at interpreting Particularized type, with female performing a higher score (64.15). This might indicate that despite the gender differences in implicature competence, both groups face the same difficulties in comprehending conversational implicatures that are culturally sensitive, which is not surprising.

Table 10

Male and female success rates on subsections

\begin{tabular}{|lll|}
\hline Gender & \multicolumn{2}{l|}{ Implicature type } \\
\hline & Generalized & Particularized \\
\hline Male & 53.37 & 36.01 \\
\hline Female & 64.15 & 51.48 \\
\hline
\end{tabular}

However, on a general basis, female learners performed higher than male learners, further item-based analysis of the responses revealed that male learners scored a little higher level of success in irony-sarcasm, and being sufficientlyinformative (respectively, item 2, male 57.1 \& female 56.7; item 7, male 28.6 \& female 23.9; item 13, male 69.0 \& female 47.8).

\section{University type comparison of implicature comprehension}

Whether public or private university offers a better quality-education has been an issue of debate, specifically in middle eastern countries. This is due to many reasons and varies according to the fields of study. In the fields of language teaching, the difference mostly relates to the teaching methods being used. In the Iraqi Kurdistan region, broadly speaking, public universities undertake the outdated grammar-translation method while new teaching methods, namely communicative language teaching methods, are followed in private universities. Regarding this issue, Table 11 displaysthe independent t-test analysis of both groups. The results revealed that private university learners $(M=9.02, S D=2.93)$ scored higher than public university learners $(M=6.62, S D=3.21)$. By traditional criteria, this variation is regarded to be extremely statistically significantdf (107) P-value $=0.0001, p<0.05$. 
Table 11

Independent t-test between the scores of private and public universities

\begin{tabular}{|ccccccccc|}
\hline $\begin{array}{l}\text { University } \\
\text { Type }\end{array}$ & $\mathbf{N}$ & Mean & $\begin{array}{l}\text { Std. } \\
\text { Deviation }\end{array}$ & $\begin{array}{l}\text { Std. Error } \\
\text { Mean }\end{array}$ & $\begin{array}{l}\text { Std. Error } \\
\text { Difference }\end{array}$ & df & t & $\begin{array}{l}\text { Sig. } \\
(2- \\
\text { tailed) }\end{array}$ \\
\hline private & 47 & 9.0213 & 2.93027 & .42742 & .59873 & 107 & 3.996 & 0.0001 \\
\hline public & 62 & 6.6290 & 3.21489 & .40829 & .59110 & \\
\hline
\end{tabular}

\section{Native and non-native comparison of implicature comprehension}

Data exhibited native speakers of English were highly successful in implicature comprehension, though it is not startling. The participants' mean score is 13.95 out of $15(S D=1.31, \min =13, \max =15)$. The comparison between native and non-native speakers (Kurdish EFL learners) displayed an extreme statistically significant difference in which, expectedly, native speakers performed much higher than non-native speakers of English. Table 12 shows the results.

Table 12

Native and non-native implicature comprehension

\begin{tabular}{|ccccccccc|}
\hline $\begin{array}{l}\text { Learner } \\
\text { Types }\end{array}$ & N & Mean & $\begin{array}{l}\text { Std. } \\
\text { Deviation }\end{array}$ & $\begin{array}{l}\text { Std. Error } \\
\text { Mean }\end{array}$ & $\begin{array}{l}\text { Std. Error } \\
\text { Difference }\end{array}$ & df & t & $\begin{array}{l}\text { Sig. (2- } \\
\text { tailed) }\end{array}$ \\
\hline Native & 20 & 13.950 & 1.3169000 & 0.2944678 & 0.751 & 127 & 8.3715 & 0.0001 \\
\hline $\begin{array}{l}\text { Non- } \\
\text { native }\end{array}$ & 109 & 7.660 & 3.303250 & 0.3163940 & & & \\
\hline
\end{tabular}

\section{ImplicaturesProduction in the L2}

Likewise, the comprehension part, in terms of appropriacy, thefindings of the DCT uncovered a low level of implicature production achievement by Kurdish EFL learners. As shown in Table 14 below, the mean scoreis 19.661 out of $48(S D=7.6524, \min =5, \max =41)$. This shows Kurdish EFL learners' low level of pragmatic competence in terms of implicature production.

Table 13

Descriptive Statistics of production implicatures

\begin{tabular}{|c|c|c|c|c|c|c|c|}
\hline & \multirow[t]{2}{*}{$\mathbf{N}$} & \multirow[t]{2}{*}{ Minimum } & \multirow[t]{2}{*}{ Maximum } & \multicolumn{2}{|l|}{ Mean } & \multirow[t]{2}{*}{ Std. Deviation } & \multirow[t]{2}{*}{ Variance } \\
\hline & & & & Statistic & Std. Error & & \\
\hline & 109 & 5.0 & 41.0 & 19.661 & .7330 & 7.6524 & 58.560 \\
\hline Valid N (listwise) & 109 & & & & & & \\
\hline
\end{tabular}

\section{The Produced Responses to DCT Items}

The output data composed of a total of 1308 responses (109x12).As Table 15 pictures,31, $2.46 \%$ of the responses were excluded from the analysis, and $19,1.51 \%$ items were left unanswered. A vast majority of the responses, 534 , $42.44 \%$, holds no implied meanings. That is, most of the participants are direct in the provision of their replies.Of the implied responses, the most frequent implicature is Quantity $306,24.32 \%$,this is, with a visible difference, followed 
by the Quality implicature 250, 19.87\%.Finally, the Relevance and Mannerimplicatures are used the least, respectively $108,8.58 \%$ and $60,2.46 \%$.

Table 14

summary of theresponses

\begin{tabular}{|lll|}
\hline Forms of response & Frequency & \% \\
\hline Explicit response & 534 & $\mathbf{4 2 . 4 4}$ \\
\hline Quantity & 306 & $\mathbf{2 4 . 3 2}$ \\
\hline Quality & 250 & 19.87 \\
\hline Relevance & 108 & $\mathbf{8 . 5 8}$ \\
\hline Manner & 60 & $\mathbf{4 . 7 6}$ \\
\hline Excluded from analysis & 31 & $\mathbf{2 . 4 6}$ \\
\hline Not responded & 19 & $\mathbf{1 . 5 1}$ \\
\hline
\end{tabular}

Moreover, the T-test was performed from the Explicit Responsesto uncover the male and female (in)directness. As Table 16 illustrates, a difference between male and female learners is revealed in which female learners( $M=3.030$, $S D=1.6327)$ are less direct than their male counterparts $(M=7.857, S D=1.8422)$. By traditional criteria, this variation is regarded to be extremely statistically significantdf (79.364) P-value $=0.001, p<0.05$.

Table 15

Explicit responses per male and female learners

\begin{tabular}{|lllllllll|}
\hline $\begin{array}{l}\text { Explicit } \\
\text { Response }\end{array}$ & $\mathbf{N}$ & Mean & $\begin{array}{l}\text { Std. } \\
\text { Deviation }\end{array}$ & $\begin{array}{l}\text { Std. Error } \\
\text { Mean }\end{array}$ & $\begin{array}{l}\text { Std. Error } \\
\text { Difference }\end{array}$ & df & t & $\begin{array}{l}\text { Sig. } \\
(2- \\
\text { tailed) }\end{array}$ \\
\hline Male & 42 & 7.857 & 1.8422 & .2843 & .2843 & 79.364 & 13.901 & 0.001 \\
\hline Female & 67 & 3.030 & 1.6327 & .1995 & .1995 & & \\
\hline
\end{tabular}

Furthermore, the results revealed, likewise implicature comprehension, in terms of appropriacy of implicature production,female learners $(M=21.701, S D=7.6831)$ performed better than male once $(M=16.405, S D=6.4470)$. By traditional criteria, this variation is also regarded to be highly statistically important $P$ value $=0.0003, p<0.05$.

Table 16

Gender-based comparison on Implicature production appropriacy

\begin{tabular}{|ccccccccc|}
\hline $\begin{array}{l}\text { Your } \\
\text { Gender }\end{array}$ & N & Mean & $\begin{array}{l}\text { Std. } \\
\text { Deviation }\end{array}$ & $\begin{array}{l}\text { Std. Error } \\
\text { Mean }\end{array}$ & $\begin{array}{l}\text { Std. Error } \\
\text { Difference }\end{array}$ & df & t & $\begin{array}{c}\text { Sig. (2- } \\
\text { tailed) }\end{array}$ \\
\hline Male & 42 & 16.405 & 6.4470 & .9948 & 1.4238 & 98.166 & 3.7196 & 0.0003 \\
\hline Female & 67 & 21.701 & 7.6831 & .9386 & 1.3677 & & \\
\hline
\end{tabular}

As per the university type, the results show that learners in private universities $(M=23.319, S D=7.0251)$ performed better than public university learners $(M=16.887, S D=6.9521)$. By traditional criteria, this variation is regarded to be extremely statistically significantdf (98.651) P-value $=0.0001, \mathrm{p}<0.05$. 
Table 17

University-based comparison in terms of implicature production appropriacy

\begin{tabular}{|ccccccccc|}
\hline $\begin{array}{l}\text { University } \\
\text { Type }\end{array}$ & $\mathbf{N}$ & Mean & $\begin{array}{l}\text { Std. } \\
\text { Deviation }\end{array}$ & $\begin{array}{l}\text { Std. Error } \\
\text { Mean }\end{array}$ & $\begin{array}{l}\text { Std. Error } \\
\text { Difference }\end{array}$ & df & t & $\begin{array}{c}\text { Sig. (2- } \\
\text { tailed) }\end{array}$ \\
\hline Public & 62 & 16.887 & 6.9521 & .8829 & 1.3507 & 98.651 & 4.7621 & 0.0001 \\
\hline Private & 47 & 23.319 & 7.0251 & 1.0247 & 1.3526 & & & \\
\hline
\end{tabular}

Finally, the results unveiled, likewise implicature comprehension, the appropriacy of native English speakers in the production of implicatures was remarkably higher than Kurdish EFL learners, though it is not surprising. Table 19 displays the results.

Table 18

Native and non-native implicature production appropriacy

\begin{tabular}{|ccccccccc|}
\hline $\begin{array}{l}\text { Learner } \\
\text { Types }\end{array}$ & $\mathbf{N}$ & Mean & $\begin{array}{l}\text { Std. } \\
\text { Deviation }\end{array}$ & $\begin{array}{l}\text { Std. Error } \\
\text { Mean }\end{array}$ & $\begin{array}{l}\text { Std. Error } \\
\text { Difference }\end{array}$ & df & t & $\begin{array}{c}\text { Sig. (2- } \\
\text { tailed) }\end{array}$ \\
\hline Native & 20 & 42.50 & 3.606 & 0.806 & 0.750 & 127 & 13.05 & 0.0001 \\
\hline $\begin{array}{l}\text { Non- } \\
\text { native }\end{array}$ & 109 & 19.66 & 7.652 & 0.733 & & & & \\
\hline
\end{tabular}

\section{Conclusions}

As people from various corners of the world connect further, the need for a mono-language proves itself more. To this end, English, to a great extent, is the sole language that connects people worldwide. Mastering a language, in our case, English does not only require linguistic competence; however, language entails different abilities, namely the functional aspects of the language. Therefore, this study aimed at assessing this competency among Kurdish EFL university students in which it specifically investigated their pragmatic competence in terms of comprehension and production of implicatures.

The results showed that KEFLUS has a low level of implicature comprehension as well as production. This is due to various reasons, yet the most concerned ones are less exposure to the language, teaching methodologies, teaching materials besides culture and mother tongue. The success level of understanding in implicatures differed based on the categories of implicature. The results indicated they have more difficulty decoding conversational implicatures that are context-dependent and sensitive to culture and suprasegmental features. For instance, the formulaic expression of "the Pope question" was interpreted by a small portion of the participants. It was uncovered in interpreting such implicatures, learners tended to decode the scenarios based on their native cultural models. This critically stresses the importance of teaching the knowledge of cultural values of the target language. As to the implicature production, though most of the responses were explicit, entailing no implicatures, even most of those implied meanings were pragmatically not appropriate depending on the target language norms. Moreover, a close interpretation of the data showed signs and influence of mother tongue transfer in either interpreting the implicature and providing responses to them. Thus, this too, stresses the importance of giving a better role and place to the teaching of pragmatic skills in the ELT programs. Moreover, these findingsreveal that in the ESL classes, especially in public universities, no adequate effort is taken to raise the learners' awareness of implicature as a communication medium or offer opportunities to practice it in the target language. 
With respect to gender, the results unveiled a significant difference in which female learners performed better in either comprehension or production of the implicatures. It was revealed that KEFLUS were more direct in their responses. Further analysis of the data showed female learners were less direct than their male counterparts. This might be due to the reason that middle eastern females are shy and introverted as well as they attach more values to politeness.

As to the university types, the results pictured students from private universities were much better than those of the public ones in both comprehension as well as production. This difference mainly attributes to the teaching methods. As it has been reported earlier, though not entirely, yet private universities use communicative methods of teaching to enable better students with the communicative aspect of the target language.

Finally, the results presented native English speakers highly outperformed, in implicature comprehension and production, to KEFLUS, though it is not surprising. We performed the entire analysis in the blockchain environment for the privacy and security of the data.

\section{Pedagogical Implications}

The results couldbenefit L2 instructors, programand coursebook writers, educational policymakers, alongthe $\mathrm{EFL/ESL} \mathrm{learners.Needless} \mathrm{to} \mathrm{say,} \mathrm{the} \mathrm{systematic} \mathrm{and} \mathrm{strategic} \mathrm{instruction} \mathrm{will} \mathrm{help} \mathrm{learners} \mathrm{to} \mathrm{obtain} \mathrm{the}$ communicative and functional skills of the target language that require pragmatic competence, specifically, conversational implicatures. As a matter of fact, linguistic competencealone shall no longer dominate the ESL/EFL classes. Instead, pragmatic competence, awareness of target language cultural values, the knowledge that communication is not always explicit, the importance of contextual clues, suprasegmental features shall be a priority in teaching a target language. Additionally, learners shall be given awareness concerning the differences, linguistic and non-linguistic, between the native and target language. This will reduce the negative transfer of the mother tongue language.Finally, in addition to the explicit instruction, exposing EFL learners to authentic materials is imperative.

\section{Declarations}

Funding : Not applicable

Conflicts of interest : The author has no conflicts of interest

Availability of data and material: Not applicable

Code availability: Not applicable

\section{References}

1. Bachman L (1990) Fundamental considerations in language testing. Oxford University Press, Oxford

2. Bachman LF, Palmer AS (1996) Language Testing in Practice: Designing and Developing Useful Language Tests. Oxford University Press, Oxford

3. Bardovi-Harlig K, Dörnyei Z (1998) Do language learners recognise pragmatic violations? Pragmatic versus grammatical awareness in instructed L2 learning. TESOL Quarterly 32(2):233-262.

https://doi.org/10.2307/3587583

Page 15/17 
4. Bardovi-Harlig K, Griffin R (2005) L2 pragmatic awareness: Evidence from the ESL Classroom. System 33(3), 401-415. https://doi.org/10.1016/j.system.2005.06.004

5. Bardovi-Harlig K, Hartford BS (1993) Learning the rules of academic talk: A longitudinal study of pragmatic change. Studies in Second Language Acquisition 15:279-304

6. Barzani SHH (2020) The Perceptions of EFL Teachers and Students on the use of Short Stories to Enhance Reading Comprehension. Asian EFL Journal 27(3.1):325-341

7. Bouton LF (1994) Conversational implicature in the second language: Learned slowly when not deliberately taught. J Pragmat 22:157-167

8. Blum-Kulka S, Olshtain E (1984) Requests and apologies: A cross-cultural study of speech act realisation patterns (CCSARP). Appl Linguist 5(3):196-213

9. Canale M (1983) From communicative competence to communicative language pedagogy. In J. C. Richards \& R. W. Schmidt (Eds.), Language and Communication, 2 (27). London: Longman

10. Canale M, Swain M (1980) Theoretical bases of communicative approaches to second language teaching and testing. Appl Linguist 1(1):1-47

11. Cenoz J (2007) The acquisition of Pragmatic Competence and Multilingualism in Foreign Language Contexts. In E. Alcon Soler, M.P. SafontJorda (Eds.), Intercultural Language Use and Language Learning, 123-140. Springer. https://doi.org/10.1007/978-1-4020-5639-0_7

12. Clark HH, Clark EV (1977) Psychology and Language: An Introduction to Psycholinguistics. New York Harcourt Brace Jovanovich

13. Crystal D (1997) English as a global language. CUP, Cambridge

14. Dornyei Z, Thurrel S (1991) Strategic competence and how to teach it. ELT Journal 45(1):16-32

15. Eslami-Rasekh Z, Eslami-Rasekh A, Fatahi A (2004) The Effect of Explicit Metapragmatic Instruction on the Speech Act Awareness of Advanced EFL Students. TESL-EJ, 8(2), 1-10. Retrieved from https://files.eric.ed.gov/fulltext/EJ1068089.pdf

16. Grice HP (1975) Logic and conversation. In: Cole P, Morgan JL (eds) Syntax and semantics: Speech acts. Academic Press, London

17. Kasper G (1992) Pragmatic Transfer. Second Language Research, 8(3), 203-231. https://doi.org/10.1177\%2F026765839200800303

18. Jianda L (2006a) Measuring interlanguage pragmatic knowledge of EFL learners. Peter Lang, Frankfurt

19. Krasner I (1999) The role of culture in language teaching. Dialogue on Language Instruction 13(1-2):79-88

20. Levinson S (1983) Pragmatics. Cambridge University Press, Cambridge

21. Lee C (2008) Requests: A cross-cultural study of interlanguage pragmatic strategy. Lambert Academic Publishing AG \& Co. KG, Germany

22. Li R, Suleiman Raja R, Sazalie A (2015) An Investigation into Chinese EFL Learners' Pragmatic Competence. Journal of Language Studies, 15(2), 101-118. Retrieved from http://ejournal.ukm.my/gema/article/view/8661

23. Muijs D (2004) Doing Quantitative Research in Education with SPSS. SAGE, London

24. Mey J (2006) Pragmatic Acts. In: Brown, Keith (eds) Encyclopedia of Language and Linguistics, 2nd edn. Elsevier, Oxford

25. Olshtain E, Cohen AD (1983) Apology: A speech-act set. In: Wolfson N, Judd E (eds) Sociolinguistics and Language Acquisition. Newbury House, Rowley, pp 18-35 
26. Olshtain E (1983) Sociocultural Competence and Language Transfer: The Case of Apology. In: Gass S, Selinker $L$ (eds) Language Transfer in Language Learning. Newbury Hous, Rowly Mass

27. Rover C (2005) Testing ESL pragmatics: Development and validation of a web-based assessment battery. Peter Lang, Frankfurt

28. Rizk S (2003) Why say NO! When you refuse?" In Z. Syed, C. Coombe, \& S. Troudi (Eds.), TESOL Arabia 2002 conference proceedings: Critical reflection and practice (pp. 401-431). Dubai, United Arab Emirates: TESOL Arabia

29. Sofi-Karim M (2015) English Language Teaching in the Kurdistan Region of Iraq. Master, Webster University. DOI: 10.13140/RG.2.1.3494.2564

30. Siddiqu A (2018) The principle features of English Pragmatics in applied linguistics. Advances in Language Literary Studies 9(2):77-80

31. Sipahi E (2021) Scale Development Study: " The Thought of the Managers Working in the Temporary Education Center about the Integration of Refugee Students to the Turkish Education System" Psychology and Education Journal. Vol. 58 No. 2 (2021): https://doi.org/10.17762/pae.v58i2.3325

32. Spackman CL (2009) Culture and Second Language Acquisition. Dominican University, Ohio

33. Thomas J (1983) Cross-cultural pragmatic failure. Appl Linguist 4(2):91-112

34. Tulgar AT (2016) The Role of Pragmatic Competence in Foreign Language Education. Turkish Online Journal on English Language Teaching 1(1):10-19

35. Viljamaa H (2012) Pragmatic competence of Finnish learners of English: Meaning in interaction in secondary and upper secondary schools. University of Turku (Unpublished), Finland

36. Wolfson N (1989) Perspectives, Sociolinguistics and TESOL. Heinle\&Heinle, Boston

37. Yule G (2010) The study of language (4th ed.) [e. book]. Retrieved from http://books.google.co.nz

38. Yule G (1996) Pragmatics. Oxford University Press, Oxford 